\title{
KAJIAN BANJIR BANDANG MASAMBA JULI 2020, TINJAUAN METEOROLOGIS
}

\author{
Masamba Flash Floods in July 2020, Meteorological Review
}

\author{
Muhamad Djazim Syaifullah ${ }^{1)^{*}}$ \\ ${ }^{1)}$ Balai Besar Teknologi Modifikasi Cuaca, Badan Pengkajian dan Penerapan Teknologi. Gd. Ir. \\ Mohammad Soebagio, Geostech 820, Kawasan Puspiptek Serpong, Tangerang Selatan. \\ *E-mail: djazim.syaifullah@bppt.go.id
}

\begin{abstract}
Intisari
Banjir bandang dan tanah longsor telah melanda kawasan Masamba, Kabupaten Luwu Utara Sulawesi Selatan, pada Senin 13 Juli 2010. Sedikitnya puluhan warga meninggal dunia dan ratusan orang luka serta belasan ribu orang mengungsi dan kehilangan harta benda. Data satelit menunjukkan adanya titik-titik longsor yang cukup banyak di wilayah hulu Sungai Sabbang, Sungai Radda, dan Sungai Masamba. Pemerintah menyebutkan bahwa bencana banjir bandang dan tanah longsor di Masamba adalah akibat curah hujan yang tinggi yang dipicu oleh adanya pertumbuhan awan Cumulonimbus (Cb). Analisis lebih detail menunjukkan bahwa beberapa hari sebelumnya daerah Sulawesi Selatan bagian tengah (termasuk juga wilayah Masamba dan sekitarnya) hampir selalu tertutupi oleh tutupan awan jenis Cumulus Congestus. Namun demikian dari analisis TRMM, wilayah Masamba bukan merupakan pusat curah hujan tertinggi. Curah hujan tertinggi berada di wilayah pantai timur Sulawesi Tengah. Adanya kejadiah hujan selama beberapa hari dan struktur tanah yang tidak mendukung memungkinkan permukaan tanah menjadi cepat jenuh, sehingga diduga menyebabkan terjadinya tanah longsor.
\end{abstract}

Kata Kunci : Banjir Bandang, GMS, TRMM, Curah Hujan, Masamba

\begin{abstract}
Flash floods and landslides hit the Masamba area of North Luwu Regency, South Sulawesi, on Monday, 13 July 2010. Many people died, and hundreds were injured, and tens of thousands were displaced and lost property. Satellite data shows that there are quite some landslides in the upper reaches of the Sabbang river, the Radda river, and the Masamba river. The government said that the flash floods and landslides in Masamba resulted from high rainfall triggered by Cumulonimbus (Cb) clouds' growth. A more detailed analysis shows that a few days earlier, the central part of South Sulawesi (including the Masamba region and its surroundings) was almost always covered by Cumulus Congestus cloud coverage. However, from the TRMM analysis, the Masamba area is not the center of the highest rainfall. The highest rainfall is in the east coast region of Central Sulawesi. The rain for several days and the unfavorable soil structure allowed the soil surface to become saturated quickly, thus causing landslides to occur.
\end{abstract}

Keywords: Flash Flood, GMS, TRMM, Precipitation, Masamba

\section{PENDAHULUAN}

Menjelang pertengahan bulan Juli 2020, tepatnya Senin malam (13 Juli 2020) sekitar pukul 19.00 WITA di wilayah Masamba dan sekitarnya, Kabupaten Luwu Utara, Sulawesi Selatan, dilanda banjir bandang yang menyebabkan puluhan orang meninggal dunia dan banyak yang hilang. Peristiwa banjir ini juga menyebabkan sekitar 15.000 warga setempat harus mengungsi. Selepas banjir surut, rumahrumah warga terendam lumpur sisa banjir.

Berdasarkan data sementara Pusat Pengendali Operasi (Pusdalops) Badan Nasional Penanggulangan Bencana (BNPB), ada sekitar 5.000 kepala keluarga yang terdampak banjir.
Terkait kerusakan yang diakibatkan banjir, Lembaga Penerbangan dan Antariksa Nasional (Lapan) memotret kerusakan banjir bandang Masamba, Luwu Utara, Sulawesi Utara dengan memanfaatkan satelit penginderaan jauh (Haryanto, 2020). Hasilnya menunjukkan banjir bandang ini melalui Kecamatan Sabbang, Masamba, Baebunta, Malangke, dan Malangke Barat. Di wilayah terdampak, banyak terdapat bangunan di pemukiman yang dilalui oleh banjir bandang. Selain itu juga banyak wilayah persawahan dan perkebunan yang rusak karena terendam oleh lumpur. Pada citra satelit, wilayah yang dilalui banjir bandang ini berwarna coklat karena keberadaan lumpur atau tanah yang mengering setelah 4 hari kejadian bencana. Data satelit ini juga menunjukkan adanya titik-titik 
longsor yang cukup banyak di wilayah hulu Sungai Sabbang, Sungai Radda, dan Sungai Masamba.

Terkait musibah ini, Badan Meteorologi Klimatologi dan Geofisika (BMKG) membuat analisis dari sisi meteorologis, yang mengungkapkan banjir bandang yang terjadi dipicu oleh hujan intensitas sedang hingga lebat, dan pertumbuhan awan Cumulonimbus (Cb).

Beberapa media menginformasikan bahwa berdasarkan data hasil pengamatan curah hujan dan satelit cuaca, memang tercatat adanya kejadian hujan dengan intensitas skala sedang hingga lebat di wilayah Masamba dan sekitarnya. Hujan intensitas sedang hingga lebat itu terjadi sejak tanggal 12 Juli 2020 atau tepatnya sehari sebelum kejadian banjir bandang tersebut, hingga sore hari tanggal 13 Juli 2020. Bahkan, analisis spasial hujan dari citra satelit cuaca juga menunjukkan hal yang sama. Hujan intensitas sedang-lebat pada tanggal 12-13 Juli 2020 tersebut, terkonsentrasi secara signifikan di wilayah utara dan timur laut wilayah Masamba dan sekitarnya yang didominasi wilayah perbukitan.

Kondisi ini cukup menarik mengingat kejadian hujan lebat yang menyebabkan banjir terjadi pada bulan Juli yang mana sebagian besar wilayah Indonesia memasuki musim kemarau. BMKG merilis bahwa pada bulan Juni 2020 ini, sebanyak 51,2 \% wilayah Indonesia sudah memasuki musim kemarau, akan tetapi cenderung lebih basah daripada rata-rata (di atas normal). Hal ini didasarkan pada kondisi ENSO yang netral, nilai IOD yang netral, dan suhu muka laut di perairan Indonesia yang relatif hangat. Aldrian, E., Susanto, R. D. (2003), membagi curah hujan wilayah Indonesia menjadi tiga wilayah dominan, wilayah Sulawesi (wilayah A) yang mempunyai respon yang cukup kuat terhadap ENSO.

Pranita (2020), menyebut ada dua faktor meteorologis penyebab banjir bandang di Masamba, Luwu Utara, yang pertama adalah faktor atmosfer dalam hal ini adalah faktor cuaca (curah hujan, intensitas curah hujan, dan durasi curah hujan). Kemudian, faktor yang kedua adalah faktor permukaan tanah (meliputi kondisi geologis, kondisi morfologis, struktur tanah, tutupan lahan maupun drainase, dan lain-lain).

Renggono dan Syaifullah (2011), telah malakukan Meteorologis Bencana banjir Bandang di Wasior, Papua Barat yang memperlihatkan bahwa kondisi meteorologis pada saat sebelum banjir memang mendukung adanya pertumbuhan awan yang cukup besar. Kajian banjir bandang Masamba ini mencoba menelaah penyebab banjir bandang dari sisi atmosfer pada saat sebelum sampai sesaat sebelum terjadinya bencana. Beberapa analisis meteorologi dan klimatologi dilakukan untuk menjelaskan kejadian bencana meteorologis ini.

\section{DATA DAN METODE}

\subsection{Satelit GMS}

Sistem Satelit Meteorologi Geostasioner (Geostasioner Meteorology Satelit, GMS) milik Jepang pada awalnya dikembangkan oleh NASDA didesain oleh GOES Amerika dan sekarang bersama-sama dijalankan oleh NASDA dan Badan Meteorologi Jepang (Japan Meteorology Agency, JMA).

Sementara itu GMS-5 adalah generasi yang lebih canggih dengan mengunakan instrument canggih VISSR (Visible and Infrared Spin Scan Radiometer) dengan satu kanal cahaya tampak (visible - 0,55-0,9 $\mu \mathrm{m}$ ) dan tiga kanal inframerah (IR 10,5-11,5 $\mu \mathrm{m}, 11,5-12,5$ $\mu \mathrm{m}$, dan 6,5-7,0 $\mu \mathrm{m})$. Citra visible dikumpulkan pada rentang kanal 0.50-0.75 $\mu \mathrm{m}$ dengan resolusi $1.25 \mathrm{~km}^{2}$ sedangkan pada citra inframerah mempunyai resolusi $5.0 \mathrm{~km}^{2}$. Diperlukan waktu sekitar 30 menit untuk mendapatkan cakupan penuh yang mengandung 2500 narrow strips.

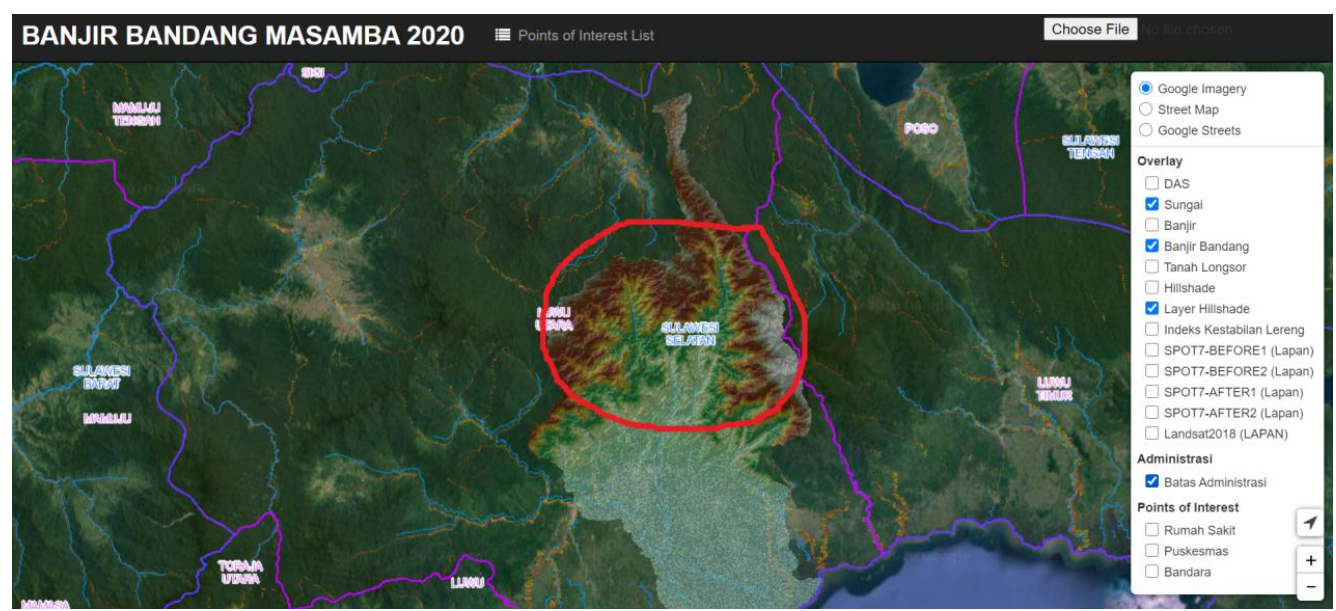

Gambar 1. Peta lokasi banjir dan banjir bandang di Masamba, Kabupaten Luwu Timur (sumber: inarisk.bnpb.go.id/) 
Tabel 1. Karasteristik spektrum masing-masing kanal untuk beberapa tipe satelit GMS.

\begin{tabular}{|c|c|c|c|c|}
\hline Kanal & $\begin{array}{l}\text { Himawari-5 } \\
\text { (GMS-5) }\end{array}$ & GOES-9 & $\begin{array}{c}\text { Himawari-6 } \\
\text { (MTSAT-1R) / } \\
\text { Himawari-7 (MTSAT-2) }\end{array}$ & $\begin{array}{l}\text { Himawari-8 / } \\
\text { Himawari-9 }\end{array}$ \\
\hline Visible (VIS) & $\begin{array}{l}0.55-0.90 \text { um @ } \\
\text { (1.25km / 6bits) }\end{array}$ & $\begin{array}{c}0.55-0.75 \text { um @ } \\
\text { (1km / 10bits) }\end{array}$ & $\begin{array}{c}0.55-0.90 \text { um @ }(1 \mathrm{~km} \mathrm{/} \\
10 \mathrm{bits})\end{array}$ & $\begin{array}{c}0.47,0.51,0.64^{*} \text { um } \\
@\left(0.5^{*}-1 \mathrm{~km} / \text { bits }\right)\end{array}$ \\
\hline Infrared 1 (IR1) & $\begin{array}{c}\text { 10.5-11.5 um @ (5km / } \\
\text { 8bits) }\end{array}$ & $\begin{array}{c}\text { 10.2-11.2 um @ } \\
\text { (4km / 10bits) }\end{array}$ & $\begin{array}{c}\text { 10.3-11.3 um @ (4km / } \\
\text { 10bits) }\end{array}$ & $\begin{array}{c}10.4,11.2 \text { um @ (2km } \\
\text { / bits })\end{array}$ \\
\hline Infrared 2 (IR2) & $\begin{array}{c}\text { 11.5-12.5 um @ (5km / } \\
\text { 8bits) }\end{array}$ & $\begin{array}{c}\text { 11.5-12.5 um @ } \\
\text { (4km / 10bits) }\end{array}$ & $\begin{array}{c}\text { 11.5-12.5 um @ (4km / } \\
\text { 10bits) }\end{array}$ & $\begin{array}{c}12.4,13.3 \text { um @ (2km } \\
\text { / bits })\end{array}$ \\
\hline Infrared 3 (IR3) & $\begin{array}{c}\text { 6.5-7.0 um @ }(5 \mathrm{~km} / \\
8 \mathrm{bits})\end{array}$ & $\begin{array}{c}\text { 6.50-7.00 um @ } \\
\text { (8km / 10bits) }\end{array}$ & $\begin{array}{c}6.5-7.0 \text { um @ }(4 \mathrm{~km} / \\
\text { 10bits })\end{array}$ & $\begin{array}{c}\text { 6.2, 6.9, 7.3, 8.6, } 9.6 \\
\text { um @ (2km / bits) }\end{array}$ \\
\hline Infrared 4 (IR4) & Not Available & $\begin{array}{c}3.80-4.00 \text { um @ } \\
\text { (4km / 10bits) }\end{array}$ & $\begin{array}{c}3.5-4.0 \text { um @ }(4 \mathrm{~km} / \\
\text { 10bits })\end{array}$ & 3.9 um @ (2km / bits) \\
\hline Infrared 4 (IR4) & Not Available & $\begin{array}{c}\text { 3.80-4.00 um @ } \\
\text { (4km / 10bits) }\end{array}$ & $\begin{array}{c}3.5-4.0 \text { um @ } \\
\text { 10bits })\end{array}$ & 3.9 um @ (2km / bits) \\
\hline Near Infrared (NIR) & Not Available & Not Available & Not Available & $\begin{array}{c}0.86^{*}, 1.6,2.3 \text { um @ } \\
\left(1^{*}-2 \mathrm{~km} / \text { bits }\right)\end{array}$ \\
\hline Frequency & 1 hour & 1 hour & 1 hour & 10 minutes \\
\hline $\begin{array}{l}\text { Position (Eq. / } \\
35,800 \mathrm{~km})\end{array}$ & $140 \mathrm{E}$ & $155 \mathrm{E}$ & $\begin{array}{l}140 \mathrm{E} \text { (MTSAT-2 in } \\
\text { standby at } 145 \mathrm{E} \text { ) }\end{array}$ & $140.7 \mathrm{E}$ \\
\hline
\end{tabular}

Satelit GMS mempunyai nama panggilan 'Himawari'. Beberapa satelit GMS mempunyai posisi dan orbit yang berbeda serta membawa beberapa peralatan dan sensor dengan karasteristik yang berbeda pula seperti disajikan dalam Tabel 1. Syaifullah dan Nuryanto (2016), telah melakukan pemanfaatan data satelit GMS multikanal untuk informasi perawanan dalam rangka kegiatan Teknologi Modifikasi Cuaca dengan hasil yang memuaskan, dengan kombinasi multikanal dapat diidentifikasi jenis awan cumulus yang merupakan target penyemaian awan.

\subsection{TRMM (Tropical Rainfall Measuring Mission)}

Data presipitasi yang digunakan dalam analisis ini adalah data satelit meteorologi TRMM (Tropical Rainfall Measuring Mission). Data TRMM didapat dari satelit dengan sensornya PR (Precipitation Radar), TMI (TRMM Microwave Imager), dan VIRS (Visible and Infrared Scanner), CERES (Clouds and the Earth's Radiant Energy System), dan LIS (Lightning Imaging Sensor). Ada beberapa satelit meteorologi selain satelit TRMM, yaitu, Satelit DMSP (Defense Meteorological Satellite Program) dengan sensor SSM/I (Special Sensor Microwave Imager). Satelit Aqua dengan sensor AMSR-E (Advanced Microwave Scanning Radiometer-Earth Observing System). dan satelit NOAA (National Oceanic and Atmospheric Administration) dengan sensor AMSU-B (Advanced Microwave Sounding Unit-B).

Satelit TRMM tersebut merupakan hasil kerjasama dua badan antariksa nasional, yaitu Amerika Serikat (NASA : National Aeronautics and Space Administration) dan Jepang (NASDA: National Space Development of Japan; sekarang berubah menjadi JAXA: (Japan Aerospace Exploration Agency) (Jaxa, dalam Syaifullah, 2013).

Kondisi curah hujan memerlukan data penamatan yang cukup panjang karena wilayah
Indonesia mempunyai variabilitas curah hujan yang cukup tinggi, sementara sebaran stasiun curah hujan yang tidak merata menyebabkan keakuratan data yang cukup rendah apabila dilakukan analisis spasial maupun temporal (Feidas, 2020).

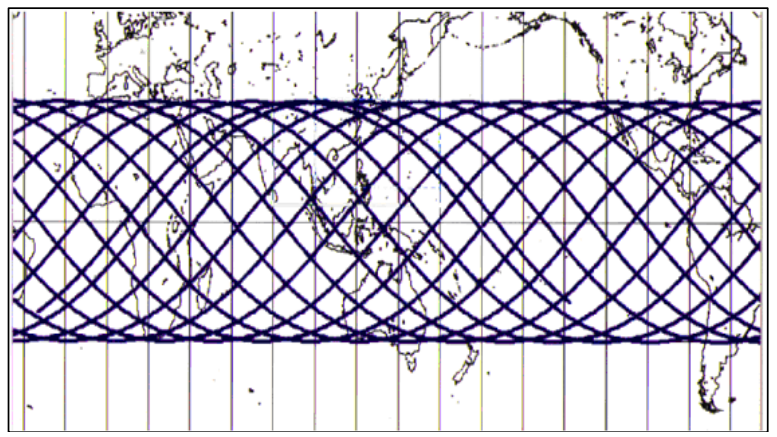

Gambar 2. Orbit satelit TRMM.

\subsection{Data}

\subsubsection{File PGM}

Format data dari file citra satelit GMS adalah format PGM. PGM kepanjangan dari Portable Graymap Format. Format PGM ini format file skala keabuan (grayscale) yang paling umum digunakan. Hal ini dirancang untuk menjadi sangat mudah digunakan dalam berbagai aplikasi. Citra PGM menyajikan sebuah gambar grafis dengan skala keabuan. Format PGM memerlukan 8 bit setiap pixel (dengan nilai minimum 0 dan maksimum 255). PGM merupakan citra mentah dengan kompresi tipe lossless. Format PGM merupakan bagian dari PGM (Portable Pixmap File Format). Format ini banyak digunakan untuk aplikasi citra saintifik.

Secara umum format PGM ini dideskripsikan sebagai berikut:

- 'Magic number', sebagai identifikasi tipe file PGM, terdiri dari dua karakter misal "P2"

- Jumlah kolom

- Jumlah baris 
- $\quad$ Nilai maksimum keabuan $(0-255)$, nilai 0 berarti warna hitam, nilai 255 berarti warna putih.

- Nilai PGM dari skala keabuan, dimulai dari kiri-atas sampai kanan-bawah.

Oleh karena file PGM masih merupakan skala kecerahan maka file tersebut belum mempunyai nilai parameter fisis (misalnya suhu puncak awan), untuk mendapatkan nilai parameter fisis tersebut dilakukan kalibrasi dengan suatu nilai tertentu. Nilai kalibrasi tersebut tersimpan dalam suatu file dengan ekstensi .CAL yang mengiringi masing-masing file PGM tersebut baik untuk kanal IR1, IR2, IR3 maupun kanal IR4.

Program untuk membaca file citra GMS dengan format PGM adalah dengan membaca file PGM masing-masing pixel dan kemudian melakukan konversi ke nilai suhu dengan file kalibrasi.

Pengunduhan file GMS dilakukan setiap jam sekali untuk masing-masing kanal. Karena itu, untuk mempermudah proses pengunduhan maka dilakukan pengunduhan otomatis yang dikerjakan oleh computer, untuk itu perlu dibuat program sederhana (script file) untuk menanganinya.

Dalam pengelolaan file citra satelit PGM ini data diolah dengan fasilitas GrADS (Grid Analysis and Display System). GrADS merupakan software interaktif yang digunakan untuk memanipulasi dan visualisasi data sains kebumian secara mudah, menampilkannya dalam bentuk grafik seperti grafik garis, grafik batang, grafik kontur, grafik kontur berarsir, vektor angin, ataupun garis alur (streamlines), data-data berbentuk grid dan data dari stasiun pengamatan .GrADS memiliki versi untuk :Unix, Linux, Windows, Macintosh.

Macam format data yang bisa dibaca GrADS: netCDF, GRIB (GRldded Binary), HDFSDS (Hierarchical Data Format - Scientific Data Format), dan format biner stream. Grads dapat diperoleh dari internet secara bebas di http://grads.iges.org/grads/downloads.html.

Untuk melakukan pengolahan file GRD dengan aplikasi GrADS diperlukan file kontrol yang menerangkan format dan layout dari file binary tersebut sehingga GrADS mampu mengenali dan membacanya. File kontrol berisi informasi tentang alamat (path) dari file binary tersebut, tipe format binary, ukuran horizontal file (latitude, longitude, start, interval), ukuran vertikal file (berapa level ketinggian), ukuran temporal file (interval waktu dan saat waktu mulai), jumlah variabel dan nama variabel.

Untuk dapat menentukan jenis ataupun tipe awan diperlukan beberapa konfigurasi kanal infra merah (IR) seperti terlihat pada Tabel 2. Pada kanal IR1 digunakan untuk membedakan antara puncak awan yang tinggi dengan puncak awan yang rendah. Semakin dingin temperatur puncak awan semakin tinggi puncak awan tersebut.

Untuk membedakan antara awan Cumulonimbus ( $\mathrm{Cb}$ ) dengan awan Cirrus (awanawan tipis) diperlukan konfigurasi IR1-IR2. Perbedaan kecil antara kanal IR1 dengan kanal IR2 menunjukkan awan tinggi dan tebal (Cumulonimbus) sedangkan perbedaan yang besar menunjukkan ketiadaan awan atau awanawan tipis (Cirrus). Untuk membedakan antara awan tebal (Cumulonimbus-Cb) dengan awanawan rendah dan tipis (Stratocumulus-Sc, Humilis) diperlukan konfigurasi IR1-IR3. Perbedaan kecil antara kanal IR1 dengan kanal IR3 menunjukkan awan tebal (Cumulonimbus) sedangkan perbedaan yang besar antara keduanya menunjukkan awan rendah dan tipis (Stratocumulus). Untuk melihat mikrofisis awan (fase, ukuran butir) diperlukan konfigurasi IR4IR1, Perbedaan besar antara kanal IR4 dengan kanal IR1 menunjukkan awan dengan butir air/es besar, sedangkan perbedaan yang kecil antara keduanya menunjukkan ketiadaan awan atau awan dengan butir air/es kecil (Maathuis, et. $\mathrm{al}, 2006)$.

\subsubsection{TRMM JAXA GSMapNRT}

Data hujan yang dihasilkan oleh TRMM memiliki tipe dan bentuk yang cukup beragam yang dimulai dari level 1 sampai level 3 . Syaifullah (2014) menjelaskan beberapa jenis level tersebut dan diagram alir algoritma TRMM untuk mendapatkan level dan tipe data tertentu, termasuk input data dan outputnya serta bagaimana mendapatkan nilai hujan dalam bentuk millimeter.

Tabel 2. Spesifikasi kanal imaginer.

\begin{tabular}{|c|c|c|}
\hline No & Konfigurasi kanal & Fungsi \\
\hline 1 & IR1 & $\begin{array}{r}\text { Untuk membedakan antara puncak awan yang tinggi dengan puncak awan yang rendah. } \\
\text { Semakin dingin suhu puncak awan semakin tinggi puncak awan tersebut. }\end{array}$ \\
\hline 2 & IR1-IR2 & $\begin{array}{r}\text { Untuk membedakan antara awan cumulonimbus dengan awan cirrus tipis. Perbedaan kecil } \\
\text { menunjukkan awan tinggi dan tebal (cumulonimbus) sedangkan perbedaan yang besar } \\
\text { menunjukkan ketiadaan awan atau awan tipis (cirrus) }\end{array}$ \\
\hline 3 & IR1-IR3 & $\begin{array}{r}\text { Untuk membedakan antara awan cumulonimbus dengan awan rendah. Perbedaan kecil } \\
\text { menunjukkan awan tebal (cumulonimbus) sedangkan perbedaan yang besar menunjukkan } \\
\text { awan rendah dan tipis (cumulus) }\end{array}$ \\
\hline 4 & IR4-IR1 & $\begin{array}{r}\text { Untuk membedakan mikrofisika puncak awan (fase, ukuran). Perbedaan besar menunjukkan } \\
\text { awan dengan butir air/es besar sedangkan perbedaan yang kecil menunjukkan ketiadaan } \\
\text { awan atau awan dengan butir air/es kecil }\end{array}$ \\
\hline
\end{tabular}


Pada hasil akhirnya nanti, beberapa data dari hasil analisis beberapa satelit meteorologi digabungkan/dikombinasikan untuk memproduski data hujan (presipitasi) yang disebut dengan produk TRMM Multisatellite Precipitation Analysis (TMPA) yang memiliki tingkat akurasi data lebih baik dari data aslinya.

Tabel 3. merupakan tabel karasteristik kedua tipe data TRMM baik dari NASA (3B42RT) maupun dari Jaxa (gsmap_nrt). Dilihat dari resolusi spasial maupun temporal maka GSMap_NRT lebih baik dibandingkan dengan 3B42RT.

Tabel 3. Karasteristik data TRMM antara produk NASA (3B42RT) dan produk JAXA (GSMap_NRT).

\begin{tabular}{|c|c|c|}
\hline Parameter & 3B42RT & GSMap_NRT \\
\hline Produk & NASA & JAXA \\
\hline $\begin{array}{c}\text { Resolusi } \\
\text { Spasial }\end{array}$ & $0.25^{\circ}$ Lat/Lon & $0.10^{\circ}$ Lat/Lon \\
\hline $\begin{array}{c}\text { Resolusi } \\
\text { Temporal }\end{array}$ & $3 \mathrm{jam}$ & $1 \mathrm{jam}$ \\
\hline $\begin{array}{c}\text { Alamat } \\
\text { unduh : }\end{array}$ & $\frac{\underline{\mathrm{ftp}: / / \text { disc2.nascom.na }}}{\underline{\text { sa.gov/data/TRMM/G }}}$ & $\frac{\text { ftp://hokushai.e }}{\text { orc.jaxa.jp }}$ \\
\hline
\end{tabular}

Sagita dan Prasetya (2013) telah melakukan analisis citra satelit MTSAT dan TRMM menggunakan Software ER MAPPER, SATAID dan PANOPLY saat Kejadian Curah Hujan Ekstrim di Wilayah Manado. Syaifullah (2014) telah melakukan validasi data TRMM Jaxa GSMap_NRT dengan data pengamatan curah hujan aktual di tiga DAS di Indonesia. Hasilnya menunjukkan bahwa TRMM Jaxa (GSMap_NRT) lebih mendekati data pengamatan dibandingkan dengan TRMM NASA (3B42RT), sehingga dalam analisis ini dipakai data TRMM Jaxa. Untuk mengolah kedua data tersebut digunakan aplikasi GrADS. Dokumentasi tentang tools ini ada di Grads documentation di situs http://iges.org/grads. Untuk memproses file tersebut dengan GrADS diperlukan file kontrol yang berbeda disesuaikan dengan format filenya.

\subsection{Daerah Kajian}

Daerah kajian adalah wilayah kejadian tanah longsor disertai banjir bandang yang terletak di Kecamatan Masamba, Kabupaten Luwu Utara, Propinsi Sulawesi Selatan seperti dalam Gambar 3. Pola curah hujan menurut BMKG untuk wilayah Sulawesi Selatan adalah ekuatorial yang berarti mempunyai dua puncak (biasanya pada Maret dan Oktober). Untuk tahun 2020, BMKG menyebutkan bahwa curah hujan bulanan di wilayah Masamba cukup tinggi dengan sifat di atas normal.

Tulisan ini akan mencoba mengeksplorasi lebih detail terkait karasteristik curah hujan wilayah Masamba dan sekitarnya.

\section{HASIL DAN PEMBAHASAN}

Untuk mengetahui kondisi penyebab banjir di wilayah Masamba, dari faktor atmosfer dilakukan beberapa analisis yaitu analisis sinoptik, analisis citra satelit GMS, analisis citra satelit beberapa kanal, analisis spasial dan analisis temporal curah hujan. Semua analisis untuk tahun 2020 dilakukan dari bulan Januari sampai Juli 2020.

Analisis sinoptik dilakukan untuk melihat pengaruh massa udara global yang masuk ke dalam wilayah daerah kajian, dengan melihat angin gradien (gradient wind). Gambar 4 adalah gambar gradient wind untuk tanggal 12 Juli 2020 pukul $00 Z$ UTC (pukul 08 WITA). Dari gambar terlihat ada pola Sirkulasi Eddy di Timur Laut Sulawesi, Sirkulasi Eddy menyebabkan tekanan udara rendah di wilayah tersebut sehingga terjadi pembelokan angin yang mengakibatkan banyak pertumbuhan awan hujan wilayah Sulawesi.

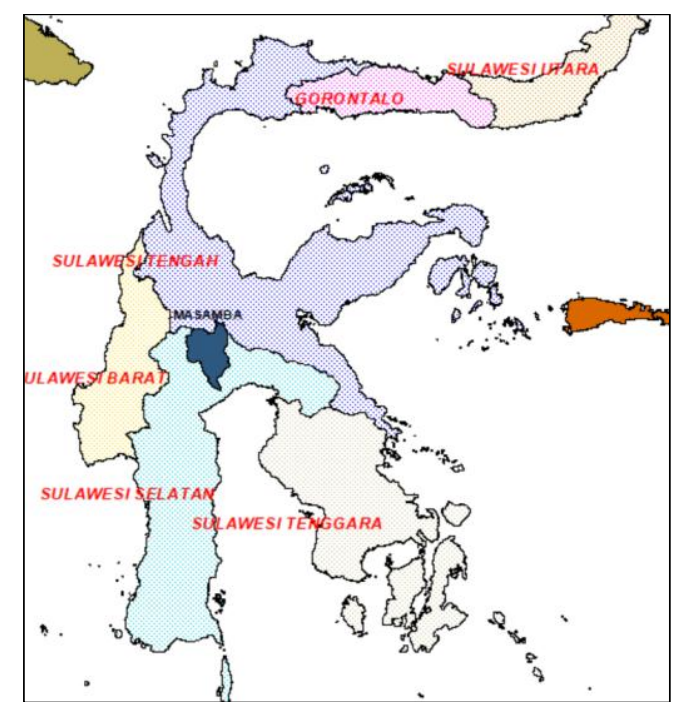

Gambar 3. Lokasi kajian wilayah Masamba, Kabupaten Luwu Utara (diarsir warna biru), Provinsi Sulawesi Selatan.

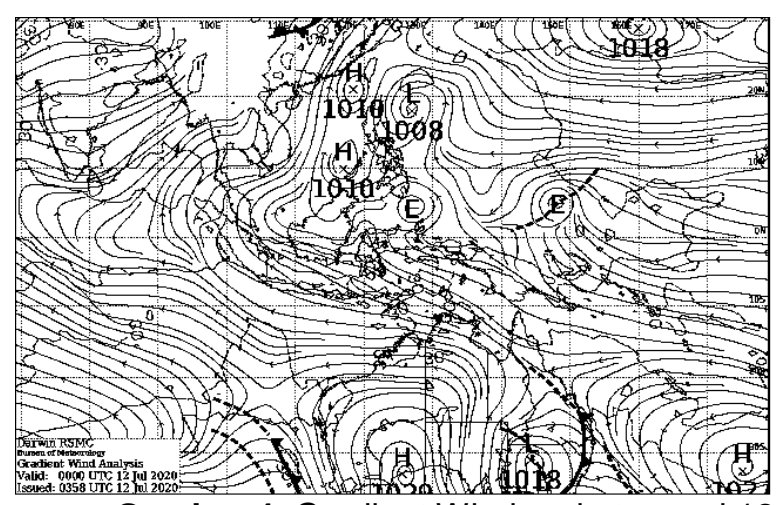

Gambar 4. Gradient Wind pada tanggal 12 Juli 2020, $00 Z$ (sumber : BOM, Australia).

\subsection{Analisis Citra Satelit GMS}

Citra satelit yang diunduh masih berupa format data PGM (Portable Graymap Format) sehingga diperlukan file kalibrasi untuk 
mengkonversi menjadi nilai Temperature Black Body (TBB). File kalibrasi telah disediakan (CAL.dat). Untuk mengolah kedua data tersebut digunakan aplikasi GrADS (Grid Analysis and Display System), sebuah tools interaktif yang sangat mudah untuk mengakses, memanipulasi, dan visualisasi data ilmu kebumian (earth sciences). Dokumentasi tentang tools ini ada di Grads documentation di situs http://iges.org/grads. Untuk memproses file tersebut dengan GrADS diperlukan file kontrol yang menerangkan format dan layout dari file binary tersebut sehingga GrADS mampu mengenali dan membacanya. Hasil pengolahan citra satelit GMS pada kanal IR1 Pada Tanggal 13 Juli 2020 dari 09.00-17.00 WITA disajikan pada Gambar 5.

Hasil pengamatan citra satelit GMS kanal IR1 beberapa hari sebelumnya menunjukkan bahwa daerah Sulawesi Tengah bagian Tengah (termasuk juga wilayah Masamba dan sekitarnya) selama beberapa hari menjelang kejadian banjir bandang hampir selalu tertutupi oleh tutupan awan.

\subsection{Analisis Citra Satelit Beberapa Kanal}

Pengolahan citra satelit beberapa kanal juga menggunakan aplikasi GrADS dengan file kontrol yang sama, hanya file Grads Script filenya yang disesuaikan dengan masing-masing kanal seperti dalam Tabel 2.

Untuk menjelaskan jenis awan yang berada di atas wilayah Masamba dan sekitarnya beberapa hari menjelang dan saat terjadinya banjir bandang dilakukan analisis jenis awan yaitu dengan menggabungkan / mengkombinasikan kanal IR1 dan kanal IR3 dengan formula tertentu seperti yang terdapat di Tabel 2. Satiadi (2014) telah membuat catatan teknis tentang hal ini untuk pengelolaan Aplikasi SADEWA (Satellite-based Disaster Early Warning System). Contoh hasilnya dapat dilihat pada Gambar 6.

Gambar 6. menunjukkan analisis spasial citra satelit GMS nilai pada kanal IR1 dikurangi dengan nilai pada kanal IR3, nilai kecil menunjukkan awan tebal (cumulonimbus, ditunjukkan dalam warna biru/ungu) sedangkan nilai yang besar menunjukkan awan rendah dan tipis (cumulus, ditunjukkan dalam warna kuning) seperti dalam Tabel 2. Selama beberapa hari menjelang kejadian banjir bandang wilayah Masamba sebagian besar tertutupi oleh awan
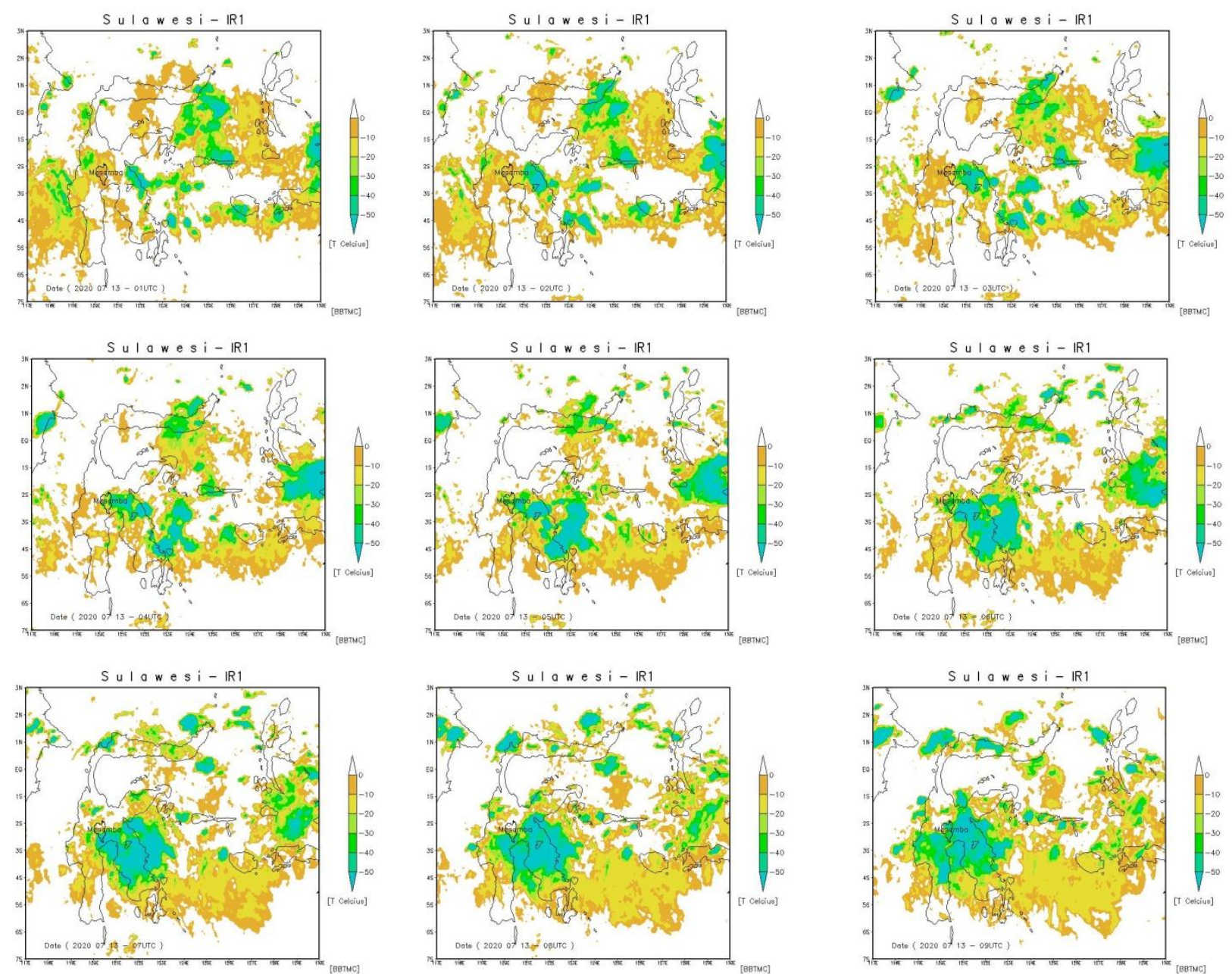

Gambar 5. Analisis spasial citra satelit GMS kanal IR1 wilayah Sulawesi pada tanggal 13 Juli 2020 dari jam 01-09 UTC (09.00-17.00 WITA) (diolah dari http://weather.is.kochi-u.ac.jp/sat/GAME/). 

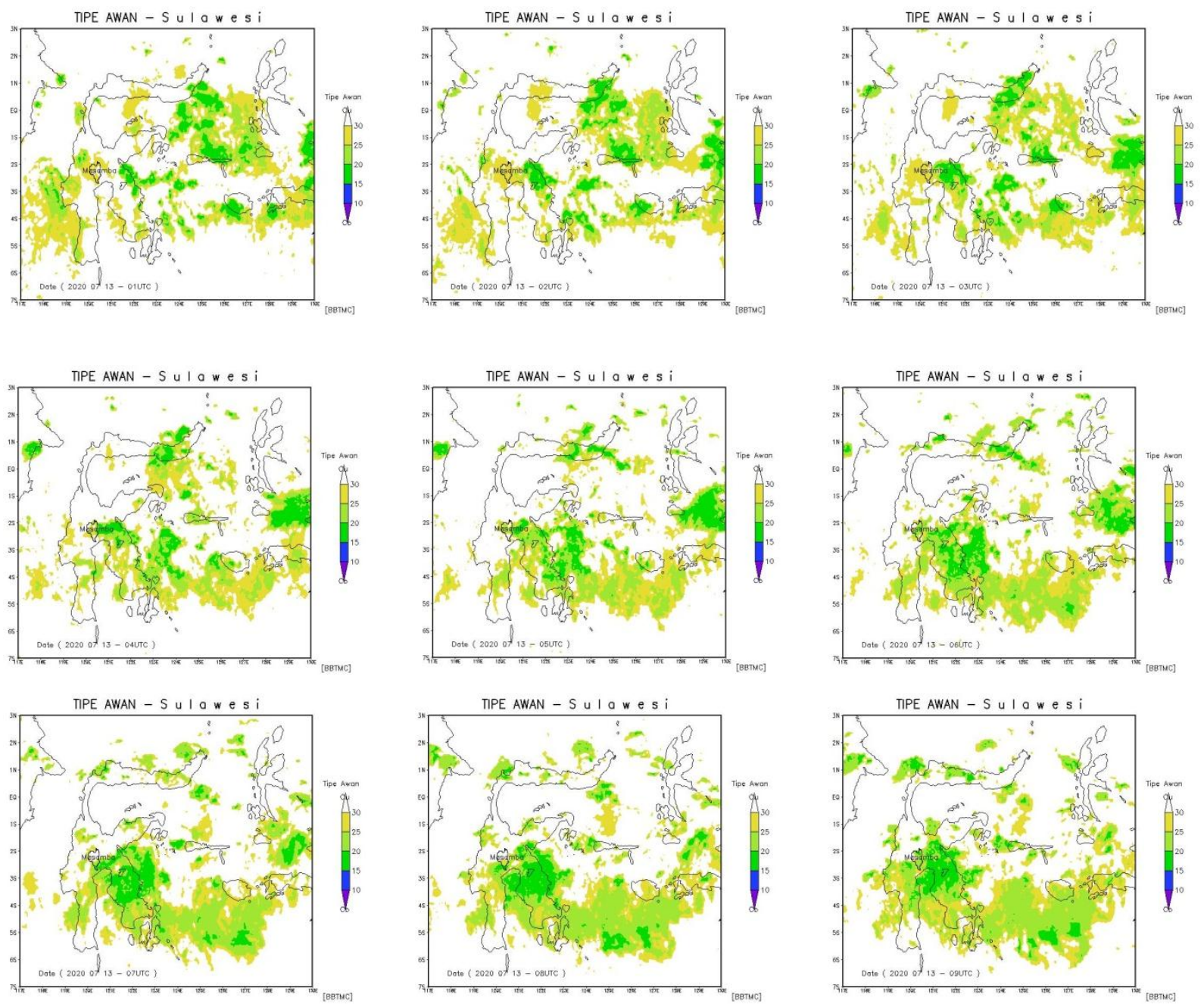

Gambar 6. Analisis spasial citra satelit GMS kanal IR1-IR3 (tipe awan) wilayah Sulawesi pada tanggal 13 Juli 2020 dari jam 01-09 UTC (09.00-17.00 WITA) (diolah dari http://weather.is.kochi-u.ac.jp/sat/GAME/).

jenis Cumulus Congestus yang cukup tebal yang hampir mencapai fase Cumulonimbus memasuki wilayah Masamba mulai dari arah Tenggara melebar sampai sebelah timur Masamba. Sehingga secara umum, wilayah yang mendapatkan tutupan awan yang cukup tebal tidak hanya wilayah Masamba saja tetapi meluas di bagian timur, tenggara, dan selatannya

\subsection{Analisis Spasial Curah Hujan}

Analisis spasial curah hujan dilakukan untuk melihat sebaran curah hujan di wilayah terdampak. Untuk melihat pengaruh curah hujan intensitas tinggi yang dapat menyebabkan banjir perlu dilihat sebaran curah hujan beberapa hari sebelumnya yaitu, mulai dari tanggal 6 Juli sampai dengan tanggal 14 Juli 2020. Hasil analisis curah hujan dengan data TRMM Jaxa GSMap_NRT disajikan dalam Gambar 7.

Gambar 7. memperlihatkan curah hujan spasial di wilayah Sulawesi bagian tengah mulai dari tanggal 6 sampai 14 Juli 2020. Dari selang waktu tersebut terlihat bahwa wilayah Masamba dan sekitarnya hampir setiap hari mengalami curah hujan. Dari analisis curah hujan beberapa hari sebelum kejadian, wilayah Masamba bukan merupakan pusat curah hujan tertinggi. Curah hujan tertinggi berada di wilayah pantai timur Sulawesi Tengah mencapai di atas $150 \mathrm{~mm} / \mathrm{hari}$. Namun demikian adanya kejadiah hujan selama beberapa hari sebelumnya memungkinkan permukaan tanah menjadi cepat jenuh, sehingga perlu dilihat struktur tanah permukaan dan tutupan vegetasi yang menyebabkan terjadinya tanah longsor.

\subsection{Analisis Temporal Curah Hujan}

Analisis temporal curah hujan digunakan salah satunya untuk mengetahui pola curah hujan, curah hujan tahunan, kecenderungan dan sebaran temporal curah hujan di wilayah Masamba. Analisis temporal yang pertama adalah pola curah hujan tahunan wilayah Masamba seperti dalam Gambar 8, yang diambil dari tahun 2009 sampai tahun 2020 (Januari-Juli) dan pola curah hujan bulanan seperti Gambar 9 . 

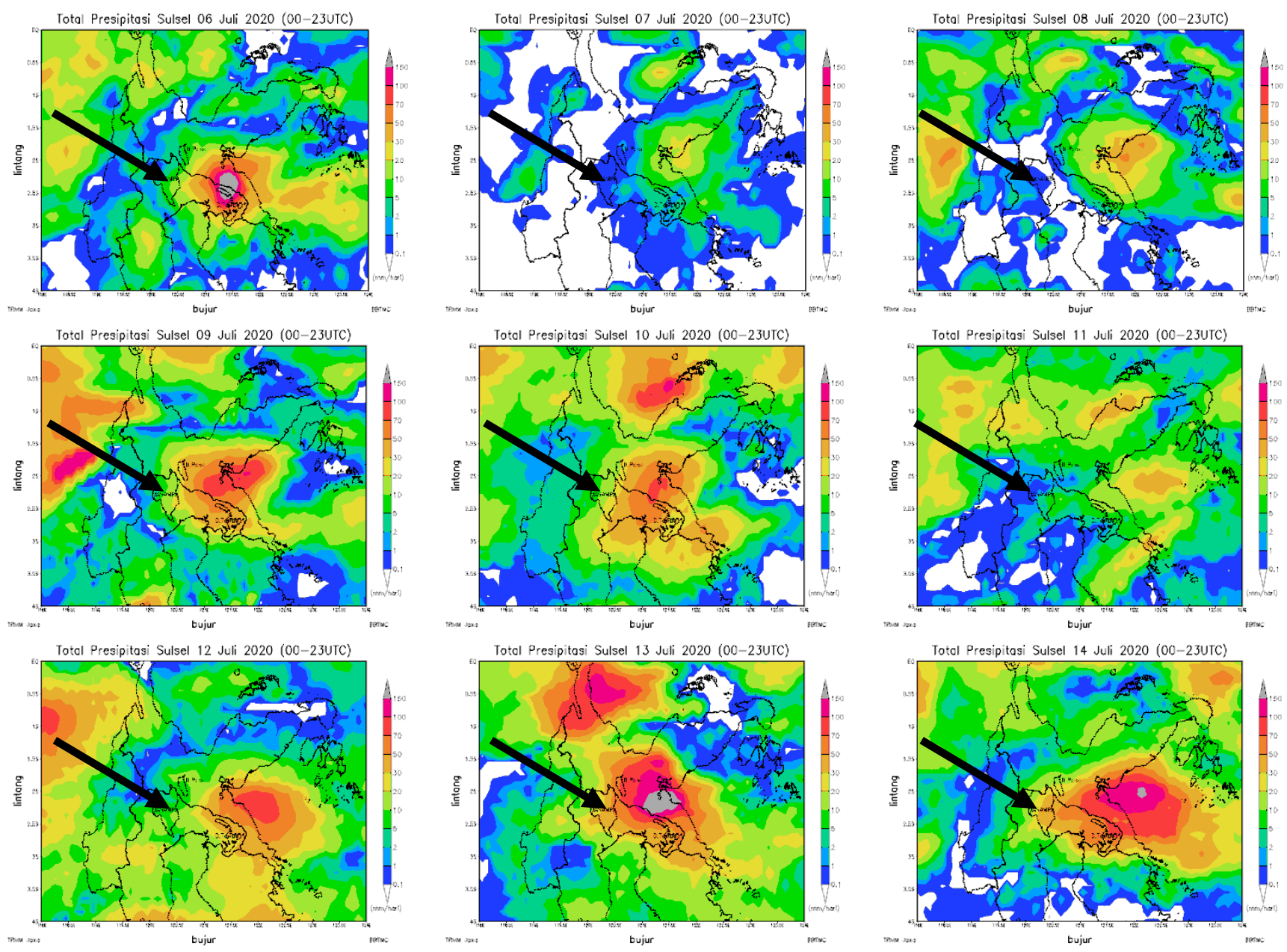

Gambar 7. Analisis spasial curah hujan wilayah Sulawesi Selatan dari tanggal 6-14 Juli 2020 (diolah dari TRMM JAXA GSMap_NRT).

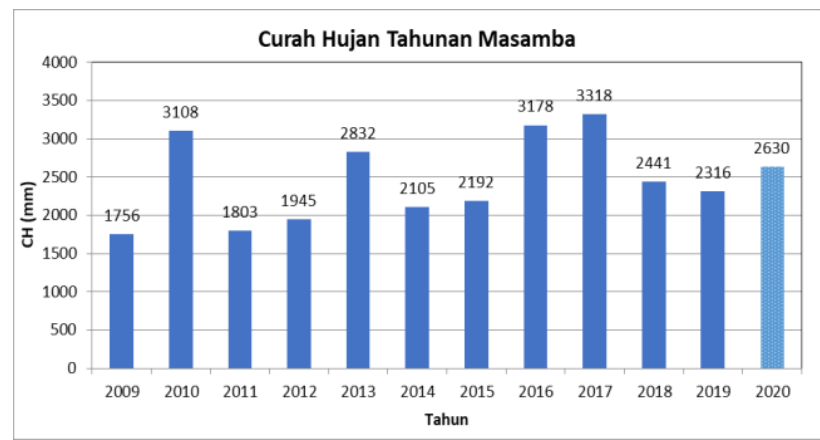

Gambar 8. Pola curah hujan tahunan wilayah Masamba, Luwu Utara (sampai Juli 2020).

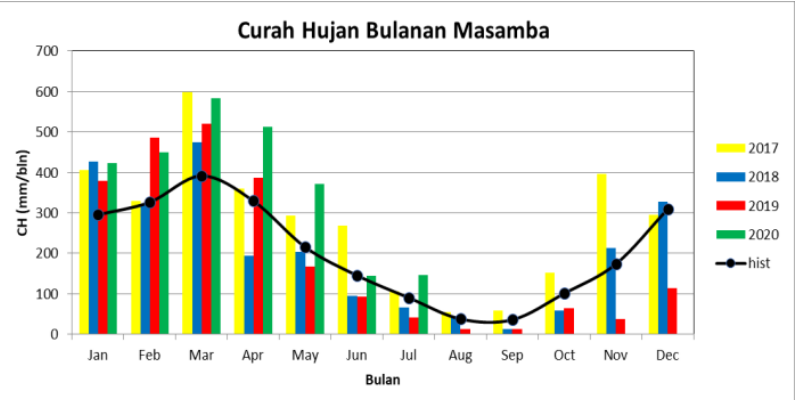

Gambar 9. Pola curah hujan bulanan wilayah Masamba, Luwu Utara.
Akumulasi curah hujan tahun 2020 cukup besar yaitu mencapai $2600 \mathrm{~mm}$ hanya dari bulan Januari sampai Juli 2020. Hal ini memperkuat prediksi BMKG yang menyatakan bahwa tahun 2020 adalah tahun basah. Hal itu juga terlihat pada curah hujan bulanan pada tahun 2020 (warna hijau) yang sebagian besar berada di atas normal seperti pada Gambar 9. Hal ini menunjukkan bahwa permukaan tanah wilayah Masamba sudah cukup jenuh sebelum terjadinya banjir bandang dan tanah longsor.

Meskipun secara umum pola curah hujan wilayah Sulawesi Selatan adalah ekuatorial (terdapat dua puncak) tapi untuk wilayah Masamba puncak keduanya tidak begitu terlihat. Rerata curah hujan bulanan tahun 2020 dari bulan Januari sampai Juli berada di atas normal sekitar $45 \%$, sehingga sejak awal tahun 2020 wilayah Masamba permukaan tanahnya sudah cukup basah akibat curah hujan yang di atas rerata.

Gambar 10 menunjukkan kecenderungan curah hujan wilayah Masamba mulai tahun 2009 sampai dengan Juli 2020. Dari curah hujan bulanan, terdapat kecenderungan untuk mengalami peningkatan curah hujan. 


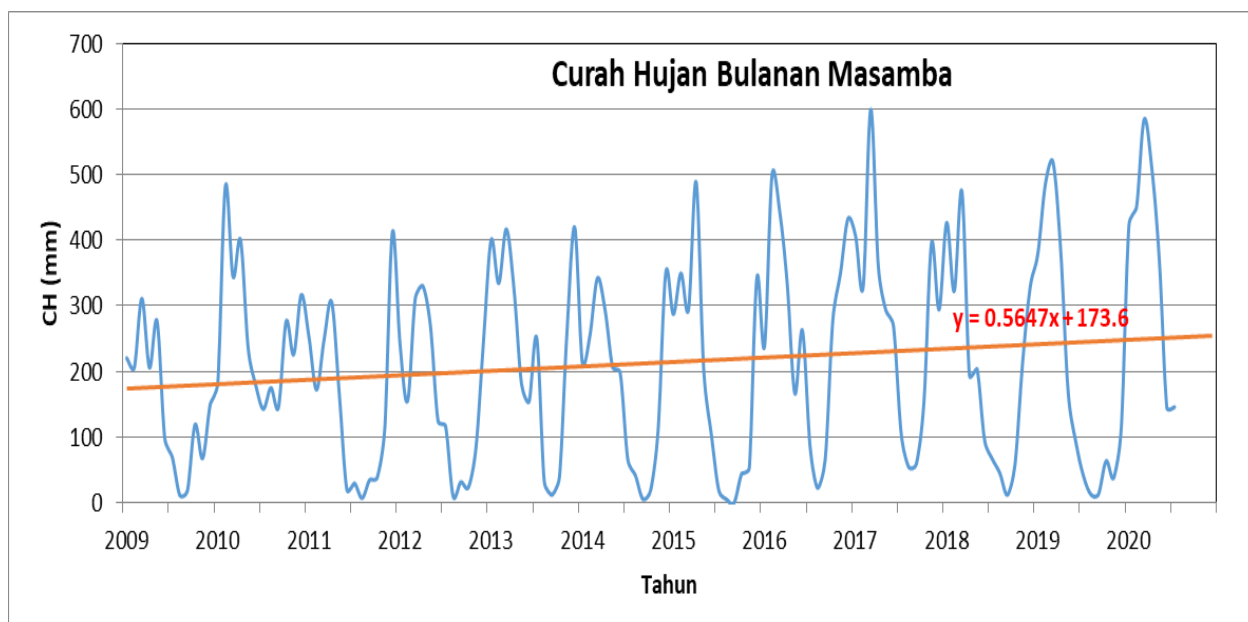

Gambar 10. Kecenderungan curah hujan wilayah Masamba, Luwu Utara.

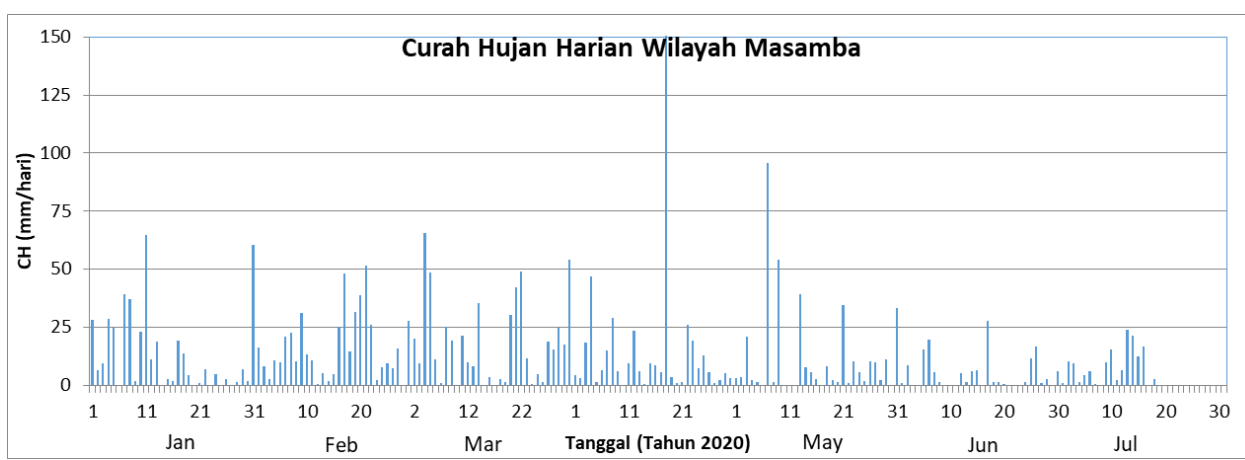

Gambar 11. Curah hujan harian wilayah Masamba, Luwu Utara sepanjang tahun 2020 (periode JanuariJuli 2020).
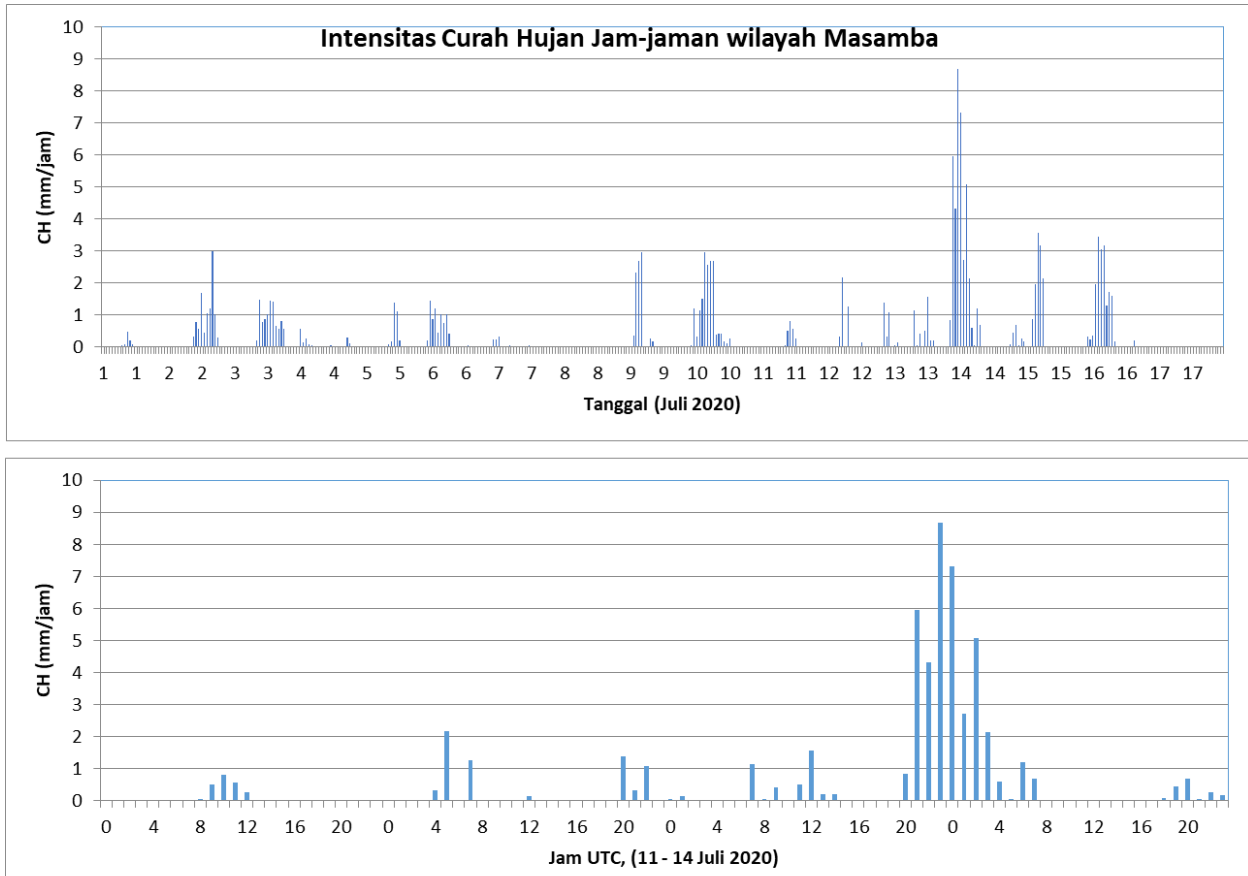

Gambar 12. Curah hujan per jam untuk wilayah Masamba, Luwu Utara pada bulan Juli 2020 (atas: tanggal 1-17 Juli 2020, bawah: 12-17 Juli 2020).

Gambar 11 merupakan curah hujan harian Masamba tahun 2020 dan Gambar 14 adalah curah hujan per jam bulan Juli 2020. Gambar tesebut menunjukkan bahwa sejak awal tahun sampai bulan Juli 2020, wilayah Masamba hampir setiap hari mengalami hujan dengan rerata curah hujan sekitar $13 \mathrm{~mm} /$ hari. Sedangkan dari curah hujan per jam justru terjadi hujan dengan intensitas tinggi di tanggal 14 Juli 2020, sehari setelah kejadian banjir bandang dan tanah longsor di Masamba, Luwu Utara (Gambar 12). 
Dari kedua hal tersebut terlihat bahwa, sejak awal tahun 2020 wilayah Masamba mengalami curah hujan yang cukup besar di atas rerata.

\subsection{Analisis Intensitas Curah Hujan}

Intensitas curah hujan memegang peranan penting bagi kejadian banjir di suatu wilayah. Untuk besar curah hujan yang sama apabila dijatuhkan dalam waktu yang pendek (intensitas tinggi) menyebabkan daya tampung permukaan untuk mengalirkan air hujan dalam waktu cepat cenderung lebih sulit dibandingkan jika dijatuhkan dalam waktu yang relatif panjang (intensitas rendah). Menurut BMKG, curah hujan dengan intensitas tinggi adalah 10-20 mm/jam atau 50-100 $\mathrm{mm} /$ hari, sedangkan intensitas sangat tinggi (ekstrem) adalah curah hujan di atas $20 \mathrm{~mm} / \mathrm{jam}$ atau di atas $100 \mathrm{~mm} /$ hari. Tabel 4 menunjukkan jumlah kejadian curah hujan dengan intensitas curah hujan (dalam $\mathrm{mm} /$ hari) di wilayah Masamba, Luwu Utara, Sulawesi Selatan.

Tabel 4. Jumlah kejadian curah hujan dengan intensitas $\mathrm{mm} /$ hari di wilayah Masamba, Luwu Utara, Sulawesi Selatan.

\begin{tabular}{|c|c|c|c|c|}
\hline \multirow{2}{*}{ Tahun } & \multicolumn{4}{|c|}{ Intensitas (mm/hari) } \\
\cline { 2 - 5 } & $>100$ & $80-100$ & $50-80$ & $20-50$ \\
\hline 2009 & 0 & 0 & 1 & 27 \\
\hline 2010 & 1 & 2 & 2 & 40 \\
\hline 2011 & 0 & 0 & 1 & 26 \\
\hline 2012 & 0 & 0 & 3 & 19 \\
\hline 2013 & 0 & 0 & 3 & 44 \\
\hline 2014 & 0 & 0 & 0 & 30 \\
\hline 2015 & 0 & 0 & 5 & 30 \\
\hline 2016 & 1 & 0 & 5 & 47 \\
\hline 2017 & 0 & 1 & 5 & 53 \\
\hline 2018 & 1 & 1 & 1 & 36 \\
\hline 2019 & 1 & 0 & 3 & 37 \\
\hline 2020 & 1 & 1 & 6 & 35 \\
\hline
\end{tabular}

Tabel 5. Jumlah kejadian curah hujan dengan intensitas $\mathrm{mm} / \mathrm{jam}$ di wilayah Masamba, Luwu Utara, Sulawesi Selatan.

\begin{tabular}{|c|c|c|c|c|}
\hline \multirow{2}{*}{ Tahun } & \multicolumn{4}{|c|}{ Intensitas (mm/jam) } \\
\cline { 2 - 5 } & $>20$ & $15-20$ & $10-15$ & $2-10$ \\
\hline 2009 & 0 & 0 & 0 & 268 \\
\hline 2010 & 3 & 3 & 5 & 490 \\
\hline 2011 & 1 & 1 & 1 & 271 \\
\hline 2012 & 0 & 0 & 0 & 295 \\
\hline 2013 & 0 & 0 & 6 & 457 \\
\hline 2014 & 0 & 0 & 0 & 330 \\
\hline 2015 & 0 & 4 & 7 & 328 \\
\hline 2016 & 1 & 6 & 7 & 483 \\
\hline 2017 & 2 & 3 & 10 & 493 \\
\hline 2018 & 5 & 5 & 5 & 337 \\
\hline 2019 & 4 & 1 & 8 & 351 \\
\hline 2020 & 4 & 3 & 10 & 382 \\
\hline
\end{tabular}

Tahun 2020 wilayah Masamba mengalami hujan ekstrem di atas $100 \mathrm{~mm} /$ hari pada tanggal 18 April 2020, curah hujan antara 80-100 $\mathrm{mm} /$ hari pada tanggal 7 Mei 2020 sedangkan curah hujan antara $50-80 \mathrm{~mm} /$ hari ada 6 kejadian yaitu pada tanggal 11 dan 31 Januari, 21 Februari, 4 dan 31 Maret, dan 9 Mei 2020.

Tabel 5 menunjukkan jumlah kejadian curah hujan dengan intensitas curah hujan (dalam $\mathrm{mm} / \mathrm{jam}$ ) di wilayah Masamba, Luwu Utara Sulawesi Selatan. Dari hasil analisis per jam kejadian hujan ekstrem di atas $20 \mathrm{~mm} / \mathrm{jam}$ terdapat 4 kejadian yang semuanya terjadi pada tanggal 18 April 2020, curah hujan antara 15-20 $\mathrm{mm} /$ hari ada 3 kejadian yaitu satu kejadian di tanggal 4 Maret dan dua kejadian di tanggal 13 Mei 2020. Dari analisis intensitas curah hujan terlihat untuk tahun 2020 mulai dari bulan Januari sampai dengan Juli 2020 wilayah Masamba mendapatkan jumlah kejadian dengan curah hujan intensitas tinggi relatif lebih banyak dibandingkan tahun-tahun sebelumnya.

\subsection{Analisis Durasi Curah Hujan}

Selain intensitas curah hujan, durasi curah hujan juga tidak kalah penting pengaruhnya terhadap kejadian banjir dan tanah longsor. Hujan dengan durasi yang panjang akan cepat membuat jenuh permukaan tanah sehingga cepat menjadi aliran permukaan. Selain itu, apabila struktur tanah tidak stabil, maka beresiko tanah longsor.

Tabel 6. Jumlah kejadian curah hujan dengan durasi tertentu (dalam jam) di wilayah Masamba, Luwu Utara, Sulawesi Selatan.

\begin{tabular}{|c|c|c|c|c|c|}
\hline \multirow{2}{*}{ Tahun } & \multicolumn{5}{|c|}{ Durasi Curah Hujan (Jam) } \\
\cline { 2 - 6 } & $=<1$ & $2-5$ & $6-10$ & $11-15$ & $>15$ \\
\hline 2009 & 138 & 187 & 61 & 14 & 9 \\
\hline 2010 & 145 & 236 & 63 & 16 & 9 \\
\hline 2011 & 140 & 155 & 46 & 13 & 4 \\
\hline 2012 & 143 & 177 & 39 & 27 & 1 \\
\hline 2013 & 148 & 212 & 69 & 22 & 5 \\
\hline 2014 & 150 & 165 & 69 & 14 & 2 \\
\hline 2015 & 110 & 141 & 53 & 22 & 4 \\
\hline 2016 & 168 & 227 & 84 & 13 & 6 \\
\hline 2017 & 191 & 233 & 94 & 27 & 2 \\
\hline 2018 & 141 & 187 & 63 & 16 & 3 \\
\hline 2019 & 119 & 153 & 44 & 20 & 6 \\
\hline 2020 & 89 & 140 & 49 & 15 & 7 \\
\hline
\end{tabular}

Tabel 6 memperlihatkan jumlah kejadian curah hujan dengan durasi tertentu dalam satuan jam (dengan nilai ambang di atas $0.2 \mathrm{~mm}$ ) di wilayah Masamba mulai tahun 2009 sampai Juli 2020. Secara umum durasi curah hujan di wilayah Masamba didominasi di atas 1 jam. Hujan dengan durasi panjang (di atas 10 jam) cukup banyak terjadi. Untuk tahun 2020 periode Januari sampai Juli, tercatat 7 kejadian hujan dengan durasi di atas 15 jam, terjadi di bulan Januari dan Februari. 


\section{KESIMPULAN}

Dari citra satelit GMS pada beberapa hari sebelum dan pada hari kejadian banjir bandang, tutupan awan tidak hanya meliputi wilayah Masamba tetapi juga dialami oleh wilayahwilayah lain di sekitarnya. Secara spasial pada saat-saat kejadian banjir, wilayah Masamba mendapatkan curah hujan yang cukup besar tetapi bukan sebagai daerah puncak hujan. Curah hujan tertinggi berada di wilayah pantai timur Sulawesi Tengah.

Faktor meteorologis bukan salah satu faktor utama penyebab terjadinya banjir bandang yang menyebabkan tanah longsor. Kondisi tanah yang sudah sangat jenuh karena curah hujan di atas normal sejak awal tahun menambah potensi terjadi banjir dan longsor. Selain itu, dari curah hujan bulanan yang memiliki kecenderungan mengalami peningkatan curah hujan menjadi hal yang perlu diwaspadai.

\section{Saran}

Perlu dikaji faktor non meteorologis yaitu penggunaan lahan, struktur batuan pembentuk lapisan tanah untuk memperjelas penyebab terjadinya banjir bandang dan tanah longsor.

\section{DAFTAR PUSTAKA}

Aldrian, E., Susanto, R. D. (2003). Identification of Three Dominant Rainfall Regions Within Indonesia And Their Relationship to Sea Surface Temperature. International Journal of Climatology, 23(12), 1435-1452, doi: $10.1002 / j$ joc.950

Feidas, H. (2010). Validation of Satellite Rainfall Products over Greece. Theoretical and Applied Climatology, 99(1), 193-216. doi: 10.1007/s00704-009-0135-8

Haryanto, Agus Tri. (2020, 18 Juli). PotretKerusakan Banjir Bandang Masamba dari Antariksa. Diakses dari https://inet.detik.com/science/d-5098885/

Maathuis, B. H. P., Gieske, A.S.M., Resios, V., Leeuween, B.V., Mannaerts, C.M., Hendrikse, J.H.M. (2006). Meteosat-8 : from Temperatur to Rainfall. Enschede:
ISPRS Commisssion VII Mid Termsymposium.

Pranita, Ellyvon. (2020, 17 Juli). 2 Faktor Meteorologis Penyebab Banjir Bandang Masamba Luwu Utara. Diakses di https://www.kompas.com/sains/read/2020/ 07/17/070200123/2-faktor-meteorologispenyebab-banjir-bandang-masamba-luwuutara?page $=$ all

Renggono, F., Syaifullah, D. (2011), Kajian Meteorologis Bencana Banjir Bandang di Wasior, Papua Barat. Jurnal Meteorologi dan Geofisika, 12(1). doi: 10.31172/jmg.v12i1.81

Sagita, N., Prasetya, R. (2013). Analisis Citra Satelit MTSAT dan TRMM Menggunakan Software ER MAPPER, SATAID dan PANOPLY Saat Kejadian Curah Hujan Ekstrim di Wilayah Manado, 16 Februari 2013. Jurnal Fisika dan Aplikasinya, 9(2). doi: 10.12962/j24604682.v9i2.843

Satiadi, D. (2014). Informasi Kanal SADEWA 3.0, Catatan Teknis No. SADEWA-TN-001, 20 Januari 2014. Pusat Sains dan Teknologi Atmosfer, LAPAN

Syaifullah, D. (2013) Kondisi Curah Hujan pada Kejadian Banjir Jakarta dan Analisis Kondisi Udara Atas Wilayah Jakarta Bulan Januari-Februari 2013. Jurnal Sains \& Teknologi Modifikasi Cuaca, 14(1), 19-27. doi: 10.29122/jstmc.v14i1.2678

Syaifullah, D. (2014). Validasi Data TRMM Terhadap Data Curah Hujan Aktual di Tiga DAS di Indonesia. J. Met \& Geo., 15(2), 109-118. doi: 10.31172/jmg.v15i2.180

Syaifullah, D., Nuryanto, S. (2016). Pemanfaatan Data Satelit GMS Multikanal untuk Informasi Perawanan dalam Rangka Kegiatan Teknologi Modifikasi Cuaca. Jurnal Sains Teknologi Modifikasi Cuaca, 17(2). doi: 10.29122/jstmc.v17i2.525

Xie, P., Yatagai, A., Chen, M., Hayasaka, T., Fukushima, Y., Liu, C., Yang, S. (2007). A Gauge-Based Analysis of Daily Precipitation over East Asia. Journal of Hydrometeorology, 8(3), 607-626. doi: 10.1175/JHM583.1 